\title{
A life-threatening haemoptysis case that would have been defined as idiopathic before the COVID-19 era
}

\author{
ilker YILMAM $^{\mathbf{1}}($ ID $)$ \\ Celal KARLIKAYA ${ }^{\mathbf{1}}$ (ID) \\ Bilkay SEREZ KAYA ${ }^{\mathbf{1}}$ (ID) \\ Osman KULA $^{2}$ (ID) \\ Hakan EMMUNGiL ${ }^{3}$ (ID)
}

${ }^{1}$ Department of Chest Diseases, Trakya University Faculty of Medicine, Edirne, Turkey

1 Trakya Üniversitesi Tıp Fakültesi, Göğüs Hastalıkları Anabilim Dalı, Edirne, Türkiye

2 Department of Radiology, Trakya University Faculty of Medicine, Edirne, Turkey

2 Trakya Üniversitesi Tıp Fakültesi, Radyoloji Anabilim Dalı, Edirne, Türkiye

${ }^{3}$ Department of Internal Medicine, Division of Rheumatology, Trakya University Faculty of Medicine, Edirne, Turkey

${ }^{3}$ Trakya Üniversitesi Tıp Fakültesi, Iç Hastalıkları Anabilim Dalı, Romatoloji Bilim Dalı, Edirne, Türkiye
Cite this article as: Yllmam i, Karllkaya C, Serez Kaya B, Kula $\mathrm{O}$, Emmungil $\mathrm{H}$. A life-threatening haemoptysis case that would have been defined as idiopathic before the COVID-19 era. Tuberk Toraks 2021;69(4):561-566.

Address for Correspondence (Yazışma Adresi)

Dr. illker YILMAM

Department of Chest Diseases,

Trakya University Faculty of Medicine,

EDIRNE - TURKEY

e-mail: drilkeryilmam@gmail.com

\footnotetext{
CCopyright 2021 by Tuberculosis and Thorax
}

Available on-line at www.tuberktoraks.org.com

\begin{abstract}
A life-threatening haemoptysis case that would have been defined as idiopathic before the COVID-19 era

The coronavirus disease 2019 (COVID-19) is characterized by respiratory infection which can show very different clinical pictures, somewhat changing medical paradigm. Hemoptysis defined as idiopathic can be seen as much as $15 \%$. Currently, increasing hemoptysis cases are being reported in medical coronavirus literature. We here present a hemoptysis case that would be defined as idiopathic before the COVID-19 era. After the first clinical picture, the case turned into a life-threatening hemoptysis. We studied the case comprehensively as clinical, pathogenetical, therapeutic and clinical practical aspects. Thus, we hypothesized that especially in the pandemic era, all hemoptysis cases must be evaluated as a possible life threatening infectious disease with unpredictable prognosis.
\end{abstract}

Key words: COVID-19; life-threatening haemoptysis; vasculitis; bronchoscopy

ÖZ

COVID-19'dan önce olsa idiopatik olarak tanımlanacak hayatı tehdit edici hemoptizi olgusu

2019 koronavirüs hastalığı (COVID-19), tıbbi paradigmayı biraz değiştirerek çok farklı klinik tablolar gösterebilen solunum yolu enfeksiyonu ile karakterizedir. Idiyopatik olarak tanımlanan hemoptizi \% 15'e kadar görülebilmektedir. Şu anda tıbbi koronavirüs literatüründe artan hemoptizi vakaları bildirilmektedir. Biz burada COVID-19 döneminden önce idiyopatik olarak tanım- 
lanacak bir hemoptizi vakayı sunmaktayız. Ilk klinik tablonun ardından olgu hayatı tehdit eden hemoptizi halini aldı. Vakayı klinik, patogenetik, terapötik ve klinik pratik yönleriyle kapsamlı bir şekilde inceledik. Biz de özellikle pandemi döneminde tüm hemoptizi olgularının prognozu belirsiz, yaşamı tehdit eden olası bir enfeksiyon hastalığı olarak değerlendirilmesi gerektiğini varsaydık.

Anahtar kelimeler: COVID-19; hayatı tehdit edici hemoptizi; vaskülit; bronkoskopi

\section{INTRODUCTION}

Even if it is researched with all available facilities including clinical examination, bronchoscopy, and thoracic computed tomography (CT), the cause cannot be determined in $10-25 \%$ of hemoptysis, and are defined as cryptogenic or idiopathic. These can be moderate or dangerous hemoptysis $(1,2)$. Dangerous hemoptysis, which is life-threatening and previously called massive haemoptysis, constitutes $5-14 \%$ of haemoptysis (3). The term "life-threatening hemoptysis" is proposed. When hemoptysis results in a life-threatening event including significant airway obstruction, significant abnormal gas exchange, or hemodynamic instability (4).

After the incubation period, the most common clinical findings in COVID-19 are fever, dry cough, myalgia and asthenia, and in more severe cases, a clinical picture that progresses to shortness of breath and respiratory failure (5). Presence of classical upper respiratory tract infection findings (rhinorrhoea, nasal congestion, sore throat, etc.) has been rarely reported in COVID-19. In many studies, changes in the sense of smell, such as anosmia and hyposmia, have been reported as early disease symptoms. More rarely, neurological symptoms (headache, confusion, altered consciousness, etc.) and gastrointestinal symptoms such as diarrhoea, especially in children, have been described in COVID-19 infection $(3,5,6)$. Hemoptysis has been reported in 3\% of COVID-19 cases in the series reported from China (6). COVID-19 cases that manifest themselves only as dangerous hemoptysis without any other symptoms may have been reported for the first time from Turkey (7).

In this study, it was aimed to present a case of massive haemoptysis which manifested itself with only a hemoptysis symptom during the pandemic period and showed no clinical, radiological (except a minimal focal image probably secondary to haemorrhage) or laboratory findings other than a positive PCR test, with comprehensive evaluations.

\section{CASE}

A 46-year-old male patient presented to the chest diseases outpatient department in February 2021 with the complaint of coughing up a small amount of blood. He was a physician working in university hospital providing pandemic-related services. He was currently a smoker (30 packs/year) and had no history of known comorbidity. The patient whose bilateral chest X-ray was normal was hospitalized because of hemoptysis that $>100 \mathrm{ml} / \mathrm{h}$ and about $150 \mathrm{ml} / 24$ hour) starting immediately after Thorax Computed Tomography (CT) scanning. In laboratory tests, the following values were detected: WBC: $8.7 \quad 10^{9} / \mathrm{L}$ (4.23-9.07), Hgb: 14.6 g/dl (13.7-17.5), Plt: 282 10 9 /L (150-400), Lym: $3.110^{9} / \mathrm{L}(1.32-3.57), \mathrm{NE}: 4.9$ 10 9 /L (3.4-6.79), Urea: $28 \mathrm{mg} / \mathrm{dl}$, Cre: $0.89 \mathrm{mg} / \mathrm{dl}$, D-dimer: $0.19 \mathrm{mg} / \mathrm{l}(0-0,55), \quad$ CRP: $0.38 \mathrm{mg} / \mathrm{dl}$ (0-0.5), ferritin: $18.3 \mathrm{ng} / \mathrm{ml}$ (23.9-336), fibrinogen: $212.71 \mathrm{mg} / \mathrm{dl}$ (170-420). In his Thorax CT, minimal focal ground-glass density in the lower left lobe (secondary to haemorrhage? secondary to infection?) noticed with difficulty (Figure 1).

Antifibrinolytic (tranexamic acid), antitussive treatments and clarithromycin treatments were started. Although he had no other clinical or laboratory findings related to COVID-19, the COVID-19 PCR (oro-nasal) test which was conducted as a routine practice due to the pandemic resulted as positive, then the patient was admitted to the pandemic service and favipiravir treatment was added to the protocol. As his blood pressure remained high during the follow-up, an antihypertensive was added. Angiography for embolization was performed on the sixth day of hospitalization due to the increase in his hemoptysis approximately $300 \mathrm{cc}$ at a time. There was no contrast leak or pseudoaneurysm in the bronchial arteries in angiograms (Figure 2). Control CT showed an increase in ground-glass densities observed in the left lower lobe laterobasal segment in the first CT. Bronchoscopy was planned for the patient who was not found suitable for embolization. 


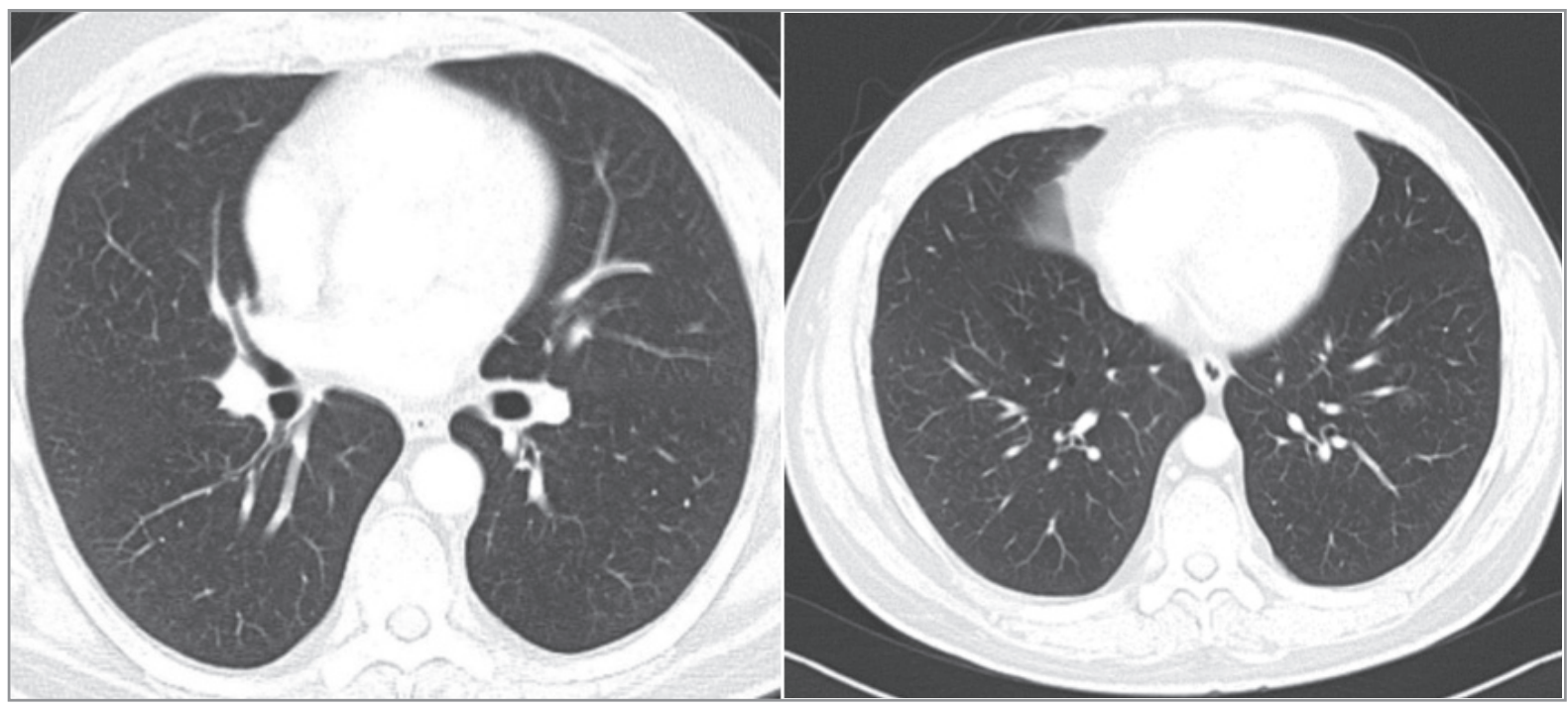

Figure 1. BT Axial section: Minimal focal ground-glass density in the lower left lobe (secondary to hemorrhage? secondary to infection?).

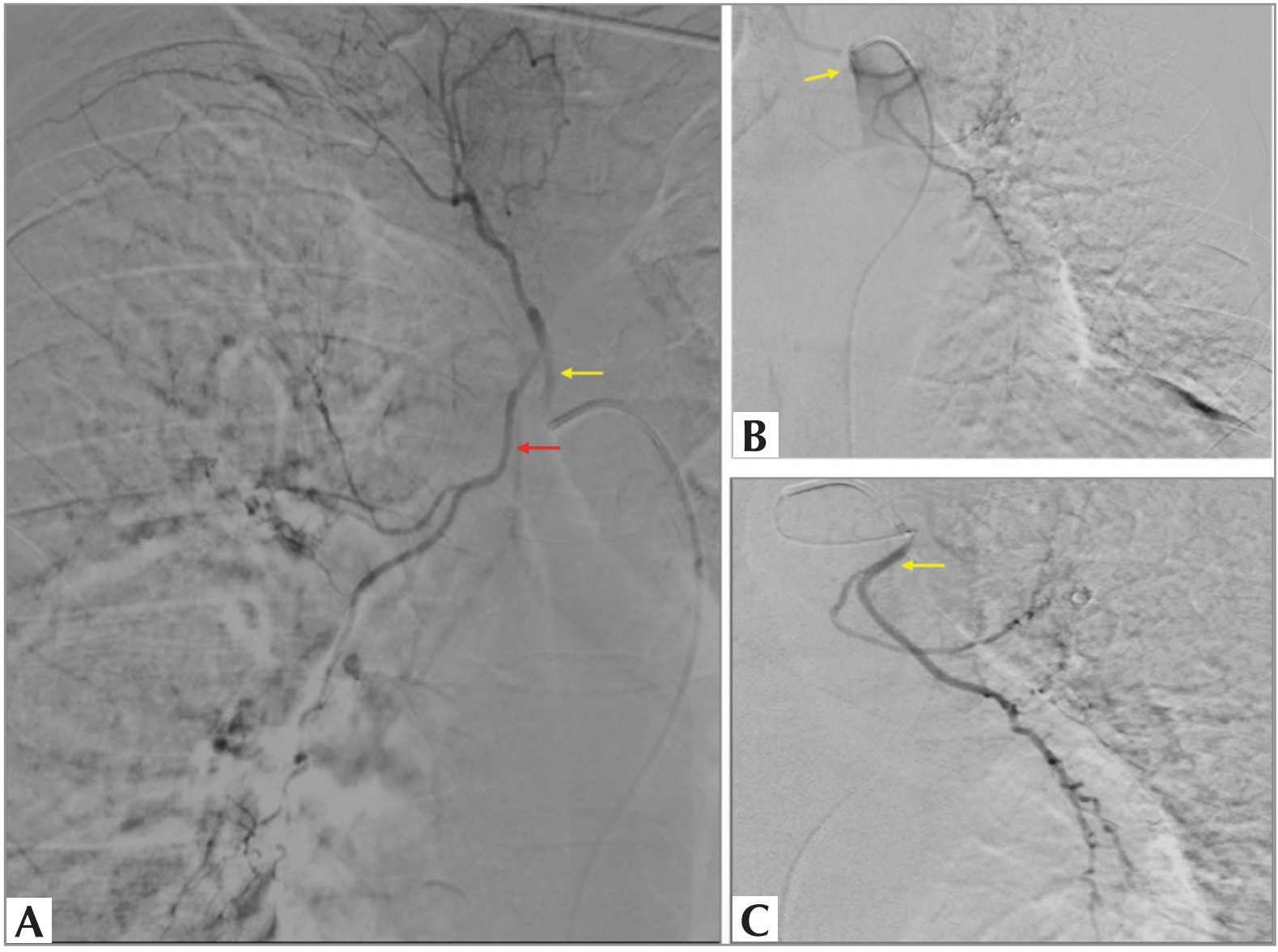

Figure 2. Bronchial arteriography image of the right common trunk (yellow arrow) and right bronchial artery (red arrow) (A). Arteriography image of the left bronchial artery (yellow arrow) with selective catheterization (B). Arteriography image of the left bronchial artery (yellow arrow) with super selective catheterization (C). There was no enlargement, tortuosity, or contrast extravasation of both the right and left bronchial arteries. 


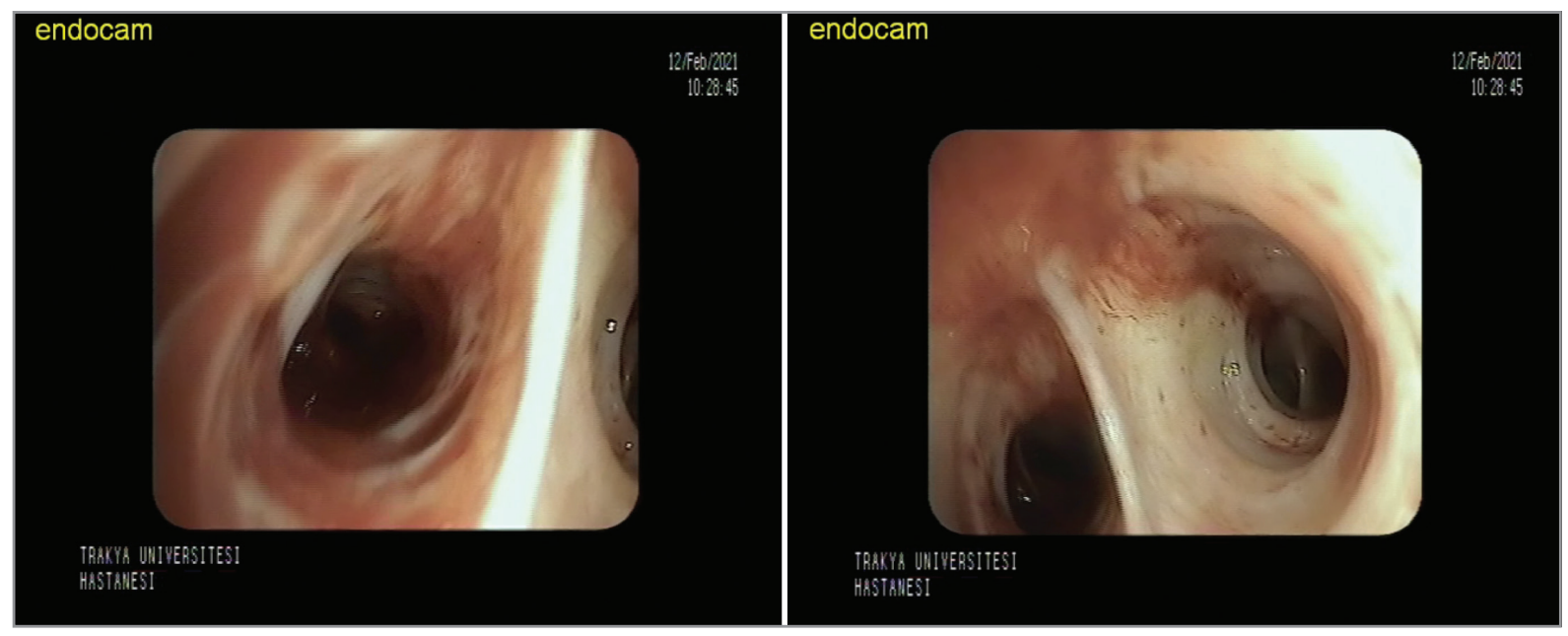

Figure 3. Bronchoscopy appearance of the patient, clot in the anterior segment of the left lower lobe is observed.

In bronchoscopy, chronic bronchitic changes in both bronchial systems and complete occlusion of the anterior subsegment of the left lower lobe were observed (Figure 3). Considering that there might be a localized small vessel vasculitis or capillaritis, dexamethasone treatment at $6 \mathrm{mg} /$ day was initiated for the patient. The second PCR result of the patient was negative. Hemoptysis did not recur in the patient's follow-ups, and was discharged on the twelfth day of his hospitalization he, with recommendation of reducing the dose of dexamethasone by half every 3 days. In the bronchoscopic lavage pathology result; respiratory epithelial cells were observed, there was no malignant cytology. Autoantibody tests including collagen tissue markers, anti-glomerular basement membrane, antiphospholipid antibodies were found to be negative in the tests completed subsequently. After 3 months, thoracic CT was reported normal.

\section{DISCUSSION}

If the PCR test had not been performed routinely due to the pandemic, this case would have been recorded as idiopathic massive haemoptysis, but after routine tests, this case was coincidentally identified as a COVID-19 disease. We evaluated that it would be correct to define it as a COVID-19 disease, since no other specific disease was primarily detected in thorax CT, bronchial arteriography, detailed biochemical and antibody tests, no haemoptysis or other symptom recurrence, and he was evaluated as healthy individual in the 6 months follow-up. In various studies, the incidence of haemoptysis due to COVID-19 disease has been reported as $0.9-5 \%$ in all cases, $0.6-4 \%$ in mild cases, and $0.3-8 \%$ in severe cases $(5,8-11)$. COVID-19 cases, which manifest themselves only as dangerous haemoptysis without any other symptoms, may have been reported for the first time from Turkey (7), but there are also other papers in the literature (12). Casey et al. (13) have reported a case of COVID19 associated with acute segmental pulmonary embolism causing haemoptysis as well.

Haemoptysis, the cause of which cannot be understood despite advanced examinations including clinical evaluations, bronchoscopy, and thorax computed tomography, is classified as idiopathic. However, as a result that can be deduced from the increasing literature in the course of this case and pandemic, it can be considered that a significant part of the cases of idiopathic hemoptysis may be of viral origin. It has been reported that viral ethology can be ignored in publications on hemoptysis, and there is massive hemoptysis in respiratory syncytial virus and influenza B pneumonia (14). It has also been shown that there may be cytomegalovirus (CMV) induced pulmonary hemorrhage in hosts without immune problems (15). It has been stated that alveolar hemorrhages in a healthy host can occur in influenza A (H1N1), dengue, leptospirosis, malaria, and staphylococcus aureus infections (16). It is also known that hemoptysis due to CMV-induced pulmonary vasculitis may develop in patients with AIDS (17). CMV, adenovirus, invasive aspergillosis, and mycoplasma, legionella, and strongyloidiasis infections may cause alveolar hemorrhages in immunodeficient patients (16).

The ethology of massive haemoptysis can vary according to the socioeconomic levels of the coun- 
tries. In countries with a low socioeconomic level, infectious diseases, especially tuberculosis, are in the first place, while malignancies are more prominent in the developed countries (18).

The fact that our patient is an active smoker can be considered as one of the factors facilitating the hemoptysis. It is also known that smoking damages alveolar epithelial cells due to oxidative stress, increases epithelial cell death, and reduces the lung repair process (19).

In our case, non-recurrence of hemoptysis after corticosteroid therapy preoccupies us that hemoptysis may have arisen from localized vasculitis - capillaritis associated with COVID-19, but non-immune mechanisms may also have played a role, such as in situ thrombosis secondary to in viral endothelitis or an embolic phenomenon. It has been histologically confirmed that COVID-19 infection may lead to cutaneous vasculitis and Kawasaki-like syndrome (20). COVID-19 can cause many hyperinflammatory syndromes as well as localized and systemic vasculitis (20).

In conclusion, in our clinical practice, we can diagnose COVID-19 by evaluating clinical findings such as fever, cough, respiratory distress and radiological findings together. However, unusual clinical findings such as hemoptysis, which can be life-threatening, may be the first manifestation of COVID-19 infection without radiological findings. This case can be considered as an example of the complexity in the pathogenesis of COVID-19 disease.

\section{CONFLICT of INTEREST}

The authors reported no conflict of interest related to this article.

\section{AUTHORSHIP CONTRIBUTIONS}

Concept/Design: All of authors

Analysis/Interpretation: IY, CK

Data Acquisition: IY, CK, OK, HE

Writing: All of authors

Critical Revision: IY, CK, BSK

Final Approval: All of authors

\section{REFERENCES}

1. Abal AT, Nair PC, Cherian J. Haemoptysis: aetiology, evaluation and outcome--a prospective study in a third-world country. Respir Med 2001; 95: 548-52.
2. Hirshberg B, Biran I, Glazer M, Kramer MR. Hemoptysis: etiology, evaluation, and outcome in a tertiary referral hospital. Chest 1997; 112: 440-4.

3. Kathuria $H$, Hollingsworth HM, Vilvendhan R, Reardon C. Management of life-threatening hemoptysis. I Int Care 2020; 8: 23.

4. Ibrahim WH. Massive haemoptysis: the definition should be revised. Eur Respir J 2008; 32(4): 1131.

5. Guan WI, Ni ZY, Hu Y, Liang WH, Ou CQ, He JX, et al. Clinical characteristics of corona-virus disease 2019 in China. N Engl J Med 2020; NEJMoa2002032.

6. Xu XW, Wu XX, Jiang XG, Xu KJ, Ma CH, Li SB, et al. Clinical findings in a group of patients infected with the 2019 novel coronavirus (SARSCov-2) outside of Wuhan, China: retrospective case series. BMJ 2020; 368: $m 606$.

7. Argun Barış S, Coşkun is, Selvi G, Boyacı H, Başyiğit $i$. Case series of COVID-19 presenting with massive hemoptysis. Turk Thorac J 2020; 21(6): 454-6.

8. Elshafeey $F$, Magdi R, Hindi $N$, Elshebiny $M$, Farrag $N$, Mahdy $S$, et al. A systematic scoping review of COVID-19 during pregnancy and childbirth. Int I Gynaecol Obstet 2020; 150(1): 47-52.

9. Zhou F, Yu T, Du R, Fan G, Liu Y, Liu Z, et al. Clinical course and risk factors for mortality of adult inpatients with COVID-19 in Wuhan, China: a retrospective cohort study. Lancet 2020; 395(10229): 1054-62.

10. Huang $C$, Wang Y, Li X, Lili R, Zhao J, Hu Y, et al. Clinical features of patients infected with 2019 novel coronavirus in Wuhan, China. Lancet 2020; 395(10223): 497-506.

11. Wang D, Hu B, Hu C, Zhu F, Liu X, Zhang J, et al. Clinical characteristics of 138 hospitalized patients with 2019 novel coronavirus-infected pneumonia in Wuhan, China. JAMA 2020; 323(11): 1061-9.

12. Peys $E$, Stevens $D$, Weygaerde $Y V$, Malfait $T$, Hermie $L$, Rogiers $P$, et al. Haemoptysis as the first presentation of COVID-19: a case report. BMC Pulm Med 2020; 20: 275.

13. Casey K, Iteen A, Nicolini R, Auten J. COVID-19 pneumonia with hemoptysis: acute segmental pulmonary emboli associated with novel coronavirus infection. Am / Emerg Med 2020; 38(7): 1544.e1-1544.e3.

14. Bond D, Vyas H. Viral Pneumonia and hemoptysis. Crit Care Med 2001; 29(10): 2040-1.

15. Magro C, Ali N, Williams JD, Allen JA, Ross Jr P. Cytomegalovirus-associated pulmonary septal capillary injury sine inclusion body change: a distinctive cause of occult or macroscopic pulmonary hemorrhage in the immunocompetent host. Appl Immunohistochem Mol Morphol 2005; 13(3): 268-72.

16. von Ranke FM, Zanetti G, Hochhegger B, Hochhegger B, Marchiori $E$, et al. Infectious diseases causing diffuse alveolar hemorrhage in immunocompetent patients: a stateof-the-art review. Lung 2013; 191(1): 9-18. 
17. Herry I, Cadranel J, Antoine M, Meharzi J, Michelson $S$, Parrot $A$, et al. Cytomegalovirus-induced alveolar hemorrhage in patients with AIDS: a new clinical entity? Clin Infect Dis 1996; 22(4): 616-20.

18. Sakr L, Dutau H. Massive hemoptysis: an update on the role of bronchoscopy in diagnosis and management. Respiration 2010; 80(1): 38-58.
19. Aoshiba K, Nagai A. Oxidative stress, cell death, and other damage to alveolar epithelial cells induced by cigarette smoke. Tob Induc Dis 2003; 1: 219-26.

20. McGonagle D, Bridgewood C, Ramanan AV, Meaney JFM, Watad A. COVID-19 vasculitis and novel vasculitis mimics. Lancet Rheumatol. 2021; 3(3): e224-e33. 